\title{
The Role of Leaders in Small Group Communication: Analysis of Speech Acts
}

\section{Nurul Afifah Adila Mohd Salleh \& Maslida Yusof}

To Link this Article: http://dx.doi.org/10.6007/IJARBSS/v11-i2/8508

DOI:10.6007/IJARBSS/v11-i2/8508

Received: 08 January 2021, Revised: 30 January 2021, Accepted: 13 February 2021

Published Online: 28 February 2021

In-Text Citation: (Salleh \& Yusof, 2021)

To Cite this Article: Salleh, N. A. A. M., \& Yusof, M. (2021). The Role of Leaders in Small Group Communication: Analysis of Speech Acts. International Journal of Academic Research in Business and Social Sciences, 11(2), 784-799.

Copyright: (c) 2021 The Author(s)

Published by Human Resource Management Academic Research Society (www.hrmars.com) This article is published under the Creative Commons Attribution (CC BY 4.0) license. Anyone may reproduce, distribute, translate and create derivative works of this article (for both commercial and non-commercial purposes), subject to full attribution to the original publication and authors. The full terms of this license may be seen at: http://creativecommons.org/licences/by/4.0/legalcode

Vol. 11, No. 2, 2021, Pg. 784 - 799

Full Terms \& Conditions of access and use can be found at http://hrmars.com/index.php/pages/detail/publication-ethics 


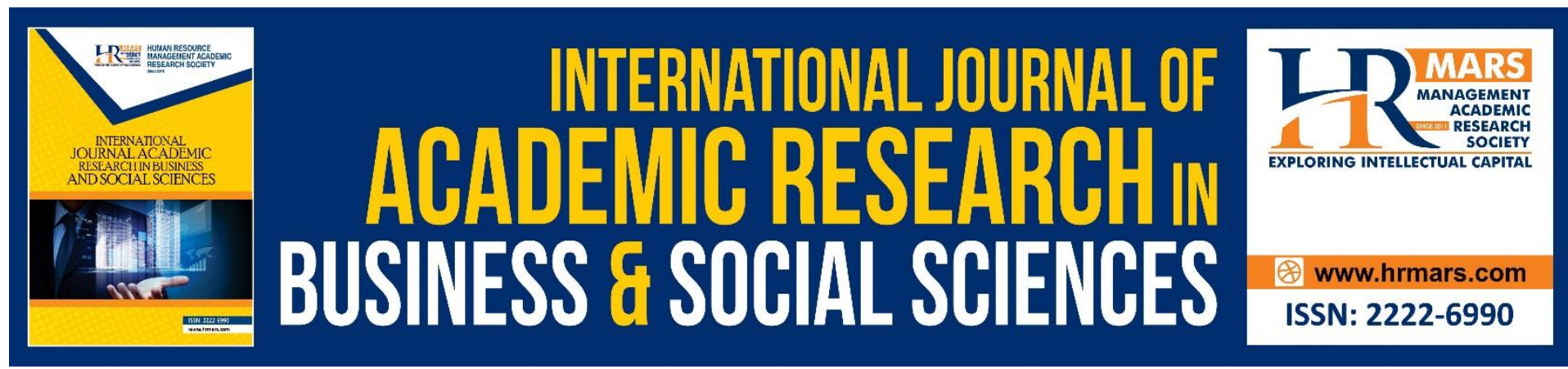

\title{
The Role of Leaders in Small Group Communication: Analysis of Speech Acts
}

\author{
Nurul Afifah Adila Mohd Salleh \& Maslida Yusof \\ Centre for Research in Malay Language, Literature and Culture, Faculty of Social Sciences \\ and Humanities, The National University of Malaysia, 43600 Bangi, Selangor, Malaysia \\ Email: afifahadila1991@gmail.com
}

\begin{abstract}
The success of a small group in achieving the goals of the discussion and adherence to the given time is undeniably influenced by the group leader. Communication that occurs in small groups will indeed use language as a medium to interact with each other. Therefore, this study was conducted to analyze the role of leaders in small group communication by looking at the use of speech acts based on the theory of Bach and Harnish (1979). A total of 60 students from Universiti Teknologi Mara (UiTM) were involved in this study. They were divided into 12 small groups and each group had appointed a leader. This small group discussion was given 10 minutes to complete the instructions given by the lecturer. The results of the study found that only four groups met the characteristics of a successful small group that is to achieve the objectives of the discussion and adhere to the set time. Therefore, only four leaders from the successful groups were analyzed to see the speech acts used. The results of the study show that the leaders of these successful groups play the role by using speech acts which are assertives, descriptives, informatives, assentives, suggestives, requestives and questions when communicating in their respective groups. This study successfully shows the pattern of the speech acts of small group leaders that can be used as a guide and reference to a small group leader who will conduct a discussion.
\end{abstract}

Keywords: Role, Group Leader, Leadership, Small Group Communication, Speech Acts

\section{Introduction}

Learning or study in a small group communication has long been a very important course or subject among university students and employees either from the private or public sector. The importance of studying in a small group communication courses is evident when the Department of Communications in various Institutions of Higher Learning offers these courses both at the degree and master level (Tamam, 1999). The field of communication of this small group is also seen to continue to gain a place among researchers from within and outside the country through various publications. Small group communication is a group discussion that involves several members. Napier and Gershenfeld (1993) state that the optimal number for a small group is five to seven members but still depends on the form of tasks and group objectives. Small groups are groups of individuals who share goals and interact with each other directly or indirectly. Devito (1997) states that groups are a collection of individuals who 
are structured and interact to achieve the same goals. Whereas Beebe and Masterson (1994) argue that small group communication is a process of interaction among individuals who share goals and feel themselves as members of a group that is interdependent and influencing each other.

Each small group formed must have several members and a leader. Leaders in a small group can be formally appointed either before or during the discussion. If a leader is not formally appointed in a small group, the character of a leader can certainly be identified indirectly when the discussion begins (Tamam, 1999). This also shows that a person can definitely play a role or function as a leader so that it can be identified even if not appointed. Role is the general behavior that an individual believes that it is appropriate in a situation in which he or she is holding a position in it. According to the Kamus Dewan Edisi Keempat (2010), role means the task performed to accomplish something. An individual will achieve a status through the role he plays. If a person acts as a leader, surely his actions and communication are like that of a leader, as well as his role as an ordinary member. Playing the role of a leader is very important to ensure that group discussions run smoothly and goals are achieved. Thus, it can be concluded that the leader in a small group has an influence in determining the success of a discussion. Baker (1997) asserts that the effectiveness of a group discussion depends on the group operator called the leader. The role of the leader is to be able to control the discussion, ensure that all members of the group are involved and communicate well so that all members can understand.

A successful leader should also be able to effectively convey information and instructions. Effective use of language is a language that can convey meaning clearly and can provoke a response or thought on behalf of the person listening or reading (Omar, 2007). Therefore, the use of the language of a leader should be given attention to see the form of language used and its effects that can contribute to the success of a group. The form of language usage chosen to focus on in this study is speech acts. The role of the group leader will be seen based on the speech acts spoken whether asking, promises, suggest, inform and others. According to Hanna and Richards (2019), speech acts serves as a human communication agent to interact and make an action. Therefore, the study of speech acts towards small group leaders is very relevant to be implemented because in communication it does contain speech acts. Speech acts in small group leader communication will be analyzed to see the effectiveness of its use and its relevance to the success of a small group discussion.

\section{Research Objective}

This study aims to analyze the speech acts of the leaders in a small group communication which based on the theory of speech acts by Bach and Harnish (1979).

\section{Literature Review}

Past studies related to small groups have been conducted extensively covering various aspects focused by researchers. Based on observations, among the things that previous researchers focused on in their study were about the design features of small group discussions such as punctuality, the role of chairman and the effectiveness of a meeting studied by Leach, Rogelberg, War and Burnfield (2009). In addition, there are also studies on small group communication behavior by Firestien (1990) and a review of group learning approaches by Katip, Bakar and Malia (2005). Next, Saedan, Jamil and Ramachanderam (2017) 
conducted a study on job satisfaction in groups, followed by Adam and Kassim (2010) who studied teamwork skills. Based on all these studies, it was found that past researchers focused their research on non-linguistic aspects. This indicates that language elements have not been widely explored or are still poorly implemented in studies related to small groups. Small group communication does use language as a medium of discussion. Juhari and Hamzah (2015) stated that the study on the use of speech acts in group communication such as meeting is very important because it can help in smoothing the discussion. Small group communication does use speech acts because every expression must have an action. Therefore, this study will examine the elements of language that is speech acts in small group discussions.

The success of a small group discussion is influenced by various factors such as social skills of group members, mastery of discussion topics, group size preparation of members before discussion and the role of group leader. This study focuses on the role of the group leader through his speech acts in ensuring successful group discussion. Baker (1997) asserts that the effectiveness of a group discussion depends on the role of the group operator called the leader. The group leader should act as the leader who can control a discussion. The role of the leader in question includes being able to control the discussion, communicate well that can be understood by other members. Because the leader plays a big role in the success of a group, then this study will examine the speech acts of the leader in small groups. A group leader is an individual who plays an important role in ensuring that a group discussion runs smoothly. Mahbob, Ali, Sulaiman and Mahmud (2019) also stressed that a leader must have communication skills to ensure that the goals of the organization to be achieved do not fail. A leader's speech or communication will have an impact and determine the success of a group discussion.

Past studies on the role of group leaders or leaders have been conducted extensively by researchers from within and outside the country. Among the studies by Ibrahim, Nordin, Delin, Baharudin, Fakurazi and Saad (2017) on the influence and role of leaders and their impact on a group. Based on this study, it can be concluded that the leader has a big role and is able to influence the actions of a group. A leader who plays a good role is able to convey specific messages to the target group. Further research by Ibrahim, Hasan and Hamid (2018) concluded that the characteristics that a leader needs to have are interpersonal communication skills, good physical appearance and ethics. Therefore, it clearly shows that the leader must play a role in determining the success of something. Communication or utterance can help a leader in conveying information and ambiguity in conveying information can jeopardize the achievement of the objectives of a group or organization (Kechot, 2015). The communication element that is the language used by a leader is something that needs to be given attention. Hughes, Ginnet and Curphy (1999) argue that the basic skill a leader needs to have is effective communication. Therefore, this study will look at the elements of language as one of the factors that determine the success of a small group discussion through its leader.

\section{Methodology}

This study selected first semester students from the Academy of Language Studies, Universiti Teknologi Mara (UiTM), Malaysia as respondents. The number of students involved is 60 people and they are divided into 12 small groups. This means a small group of 5 members. All groups were allocated 10 minutes to complete the instructions given by the lecturers they should propose a final project title they want to run either in the areas of language, linguistics 
or culture. Before the discussion begins, group members need to appoint a leader in their respective groups. The topics that have been proposed and agreed upon will be submitted to the lecturer for evaluation and consideration. Haynes (1988) states that a successful small group is a group that adheres to the allotted time and achieves the objectives of the discussion that has been set. Therefore, in the analysis section of the study findings, only successful small groups will be selected and examined the use of speech acts of group leaders. This discussion is recorded verbatim and the speech acts used will then be analyzed by using the theoretical framework of Bach and Harnish (1979). This study selects the theory of Bach and Harnish (1979) which has four taxonomies namely constatives, directives, commissives and acknowledgments.

\section{Speech Acts}

Bach and Harnish (1979) speech acts theory is seen to have a more detailed categorization in elaborating self-acknowledged speech acts by Peursem, Locked and Harnish (2001). There are four taxonomies of speech acts outlined, namely constatives, directives, commissives and acknowledgments. This theory was chosen because of its comprehensive categorization and can be fully utilized to examine the utterances during the discussion of small groups. Blakemore (1922) states that "the classification of speech acts theory plays an important role in communication act". The following are the subcategories mentioned by Bach and Harnish (1979: 41) in his book titled "Linguistic Communication and Speech Acts".

Table 1: Types of Bach and Harnish Speech Acts (1979)

\begin{tabular}{|c|c|c|c|}
\hline Constatives & Directives & Commissives & Acknowledgement \\
\hline Assertives & Requestives & Promises & Apologize \\
\hline Predictives & Questions & Offers & Condole \\
\hline Retrodictives & Requirements & & Congratulate \\
\hline Descriptives & Prohibities & & Greet \\
\hline Ascriptives & Permissives & & Bid \\
\hline Informatives & Advisories & & Accept \\
\hline Comfirmatives & & & Reject \\
\hline Concessives & & & \\
\hline Retractives & & & \\
\hline Assentives & & & \\
\hline Dissentives & & & \\
\hline Disputatives & & & \\
\hline Responsives & & & \\
\hline Suggestives & & & \\
\hline Suppositives & & & \\
\hline
\end{tabular}

Table 2 above shows four taxonomies of speech acts based on the theory of Bach and Harnish (1979). The four taxonomies are constatives, directives, commissives and acknowledgement. Constatives speech acts are seen as the most subcategory of 15 subcategories. While the directives speech acts is the second highest with six subcategories. The commissives speech acts has two subcategories and the acknowledgement speech acts has eight subcategories. 


\section{Analysis and Discussion}

Based on the 12 small groups involved in this study, it was found that only four groups met the characteristics of a successful small group as outlined by Haynes (1988). The characteristics of a successful small group are those who adhere to the allotted time and achieve the objectives of the discussion that have been set. Therefore, these four successful small groups were selected to analyze the speech acts of their group leaders only. While the other eight groups were considered unsuccessful because they did not meet the set characteristics. The speech acts according to Austin (1962) is to do the act meant by the utterance. When a person says something, it means he is doing something with the speech he utters. This theory of speech acts shows that the spoken language has its own speech acts. Thus, the basic meaning in this theory focuses on how to connect meaning and act with language. This definition coincides with Searle (1969) who stated that "speaking a language means immersing oneself into a form of act bound by rules". According to Osman et al (2012), the theory of speech acts shows that the spoken language has its own speech acts. Saying something either orally or in writing is an act of doing something. Based on the analysis of the study data, the small group leaders who are successfully used only seven speech acts which are assertives, informatives, suggestives, descriptives, assentives, requestives and questions. This study will analyze the successful group leaders to see the pattern of the speech acts can be used as a guide. Below is an analysis of examples of successful small group leader speech acts.

\section{i) Assertives}

The assertives speech acts is that which expresses the mind to express or provide information about something, such as circumstances, events, properties or anything either concrete or abstract (Omar, 1997). Bach and Harnish (1979) states that verbs that can express the assertives are affirm, allege, assert, aver, avow, claim, declare, deny, indicate, maintain, propound, say, state and submit. This study found that small group leaders only used the verbs (menegaskan) 'assert', (menyatakan) 'declare' and (mengesahkan) 'affirm' in the utterance of assertives. However, the example given below only refers to utterances that contain the verb 'assert' and 'declare'.

\section{1. so nak menegaskan tajuk kita adalah pengaruh bahasa Pijin dan bahasa Kreol dalam kehidupan masyarakat. (K1 (leader group one)] \\ 2. okay hari ini aku nak menyatakan yang kita nak bincang dan kita akan nak cari satu tajuk yang bersesuaian dengan linguistik. [K7 (leader group seven)]}

The first example is a statement by the leader of the first group (K1) who made a statement "so nak menegaskan tajuk kita adalah pengaruh bahasa Pijin dan bahasa Kreol dalam kehidupan masyarakat" which was said at the final phase of the discussion. The utterance of (K1) is marked by the explicit performative verb "menegaskan" which is "assert" as outlined by Bach and Harnish (1979). Therefore, this clearly shows the intention of the stated act expressed by the speaker. This statement by (K1) is very important because it is seen to serve to remind it's her group members that it is the title of their group. This reminder is uttered at the end of the discussion before the allotted time ends. As the leader of the group, (K1) is seen to play a role that is to give a reminder on the topic that has been agreed by his group members by making a statement. Hyland \& Yost (1994) emphasize that leaders in a group should make a reminder to its members regarding what is discussed at the end of the 
discussion. Thus, it clearly shows that (K1) plays a role as a leader through the use of his speech acts.

Meanwhile, the seventh group leader (K7) uttered the statement at the beginning of the discussion which is "okay hari ini aku nak menyatakan yang kita nak bincang dan kita akan nak cari satu tajuk yang bersesuaian dengan linguistik". The speech act of this (K7) statement is seen as very important to be uttered at the beginning of the discussion as the initiator of the discussion. As a leader, (K7) he is seen to play a role that is to open the discussion by making a statement about the purpose of their discussion that is to find a suitable topic to be proposed. This (K7) utterance is explicitly marked with the performative verb "menyatakan" which is "declare" as outlined by Bach \& Harnish (1979). Thus, it clearly shows the intention of the stated act expressed by (K7). The act of the statement can be expressed by the group leader at the beginning of the discussion to state something useful as stated by (K7) as the initiator of the discussion. Cargan and Wright (1980) in their study of communication in small groups explain that a group leader should play a role starting from the beginning of the discussion by emphasizing the main purpose of the discussion held. This will alert and remind group members regarding the purpose or objective of the discussion conducted. Based on the utterances by (K1) and (K7), the utterances of the speech acts are clearly pronounced and this shows that the group leaders play a role by making the act of assertives.

\section{ii) Descriptives}

The descriptives speech acts is to describe and explain something (Bach and Harnish, 1979). Kamus Dewan Edisi Keempat (2010) also defines descriptive aims to provide a description of something. Bach and Harnish (1979) states that verbs that can express the descriptives are appraise, assess, call, categorize, characterize, classify, date, describe, diagnose, evaluate, grade, identify, portray, and rank. However, this study found that small group leaders only used the verbs (penilaian) 'assess', (menerangkan) 'describe' and (mengenal pasti) 'identify' in the utterance of descriptives. The example given below only refers to utterances that contain the verb 'identify' and 'assess'.

1. kita boleh mengenal pasti perbezaan antara bahasa pijin dan kreol ini pijin ni bahasa ni dia bahasa kacukan yang belum mantap tapi kreol ni bahasa kacukan yang telah mantap, tapi dua-dua ramai guna. [K1 (leader group one)]

2. budaya dekat Sarawak kan dia banyak masyarakatkan, berdasarkan penilaian aku, kita kena pilih salah satu, macam kita spesifik kan kita jangan buat semua kalau semua memang gila. [K9 (leader group nine)]

Based on this statement of (K1), the word "mengenal pasti" clearly indicates the verb for descriptives speech acts. Bach and Harnish (1979) through his speech acts theory outlines the performative verb "identify" is a descriptive speech acts. (K1) is seen to make an explanation by identifying the differences between Creole and Pijin languages. This (K1) utterance is uttered in the middle phase of the discussion. (K1) is seen to play a role as a group leader by making explanatory behaviors of what he knows to share with his group members. Ellis and Fisher (1994) explain that among the problems that often occur in group discussions is that participants do not understand the instructions or what their boss says. Therefore, descriptive speech acts can be used by the group leader to explain something to his group members 
regarding the information to be conveyed. A descriptive speech act that is descriptive in nature is able to function to understand group members.

In addition, descriptives speech acts is seen as important in helping small groups to make decisions. This can be seen through the statement of (K9), the leader of the ninth group "budaya dekat Sarawak kan dia banyak masyarakatkan, berdasarkan penilaian aku, kita kena pilih salah satu, macam kita spesifik kan kita jangan buat semua kalau semua memang gila". This statement is marked by the explicit performative verb which is "penilaian". Bach and Harnish (1979) outlined the verb "assess" which means assessment is a descriptive speech acts. (K9) makes the assessment that the culture in Sarawak needs to be specified for study because there are too many choices. Therefore, this clearly shows that (K9) has the intention of descriptive that is to make an assessment. After listening to the descriptive speech acts by the leader of this group, group members will think more about making decisions to cover the culture in the state of Sarawak.

\section{iii) Informatives}

The informatives speech acts is the notification of a thing or thing that will form a previously unknown belief (Bach and Harnish, 1979). The informatives speech acts is also the intention of the action by the speaker so that the listener gets knowledge or information. Kamus Dewan Edisi Keempat (2010) states that information means giving useful information and information about something. Bach and Harnish (1979) states that verbs that can express the informatives are advise, announce, apprise, disclose, inform, insist, notify, point out, report, reveal, tell, testify. However, only the verbs (beritahu) 'tell', (nasihat) 'advise' and (mendedahkan) 'disclose' are used in the communication of successful small group leaders. Below are examples of the utterances for the verbs 'advise' and 'tell' which are considered as informatives.

1. aku nasihatkan kita kena buat perancangan sebelum kita ambik data, kita kena mintak izin dengan mereka. [K7 (leader group seven)]

2. dekat Sarawak aku nak beritahu yang kita ada Iban, kita ada Melanau. [K9 (leader group nine)]

The first example is the statement by the leader of the seventh group (K7) which is "aku nasihatkan kita kena buat perancangan sebelum kita ambik data, kita kena mintak izin dengan mereka" which was said in the middle phase of the discussion. (K7) is seen to use informatives speech acts as an effort to advice on research procedures. As a group leader, giving information by advising is highly encouraged so that group members know it and comply with it. The leader of this group is also seen as caliber because he knows and wants to follow the procedure to conduct the study. This (K7) utterance is marked with an illocution marker which is the performative verb "nasihatkan". According to Bach and Harnish (1979), the verb "advise" which is an informatives speech acts. Therefore, it is very clear that (K7) has the intention to inform about the research procedures that need to be followed.

Next (K9), the leader of the ninth group, said "dekat Sarawak aku nak beritahu yang kita ada Iban, kita ada Melanau". The action of the information presented is very important because it can provide new information to its group members regarding ethnicity in the state of Sarawak. This utterance is uttered during the initial phase of the discussion. Therefore, at this 
stage the group members are already aware of the ethnic options available in Sarawak and they can continue to focus discussions to choose between the two ethnicities. This (K9) utterance is marked by the explicit performative verb "beritahu" which is "tell" as outlined by Bach and Harnish (1979) in his speech acts theory. Therefore, this clearly shows that (K9) has the intention of informing. This informatives speech acts function serves to convey information to group members. Based on the statements of (K7) and (K9), it clearly shows that the group leader can play a role in making informed so that something can be known by its members. The action of a leader to share this information can give an example to other members to also share the information by making an informatives speech acts. Fisher (1980) stated that a group leader should always provide useful information and encourage other members to share ideas so that the discussion will be more useful and immediately achieve the goal. Therefore, this clearly shows that a group leader needs to play a role in conveying information by using informatives speech acts.

\section{iv) Assentives}

Bach and Harnish (1979) stated that the assentives speech acts is to agree with the statements expressed by the speaker. Kamus Dewan Edisi Keempat (2010) states the meaning of acceptance is about accepting something, approving or agreeing. Bach and Harnish (1979) states that verbs that can express the assentives are accept, agree, assent and concur. However, only the verbs (terima) 'accept' and (setju) 'agree' are used in the communication of successful small group leaders. Below are examples of utterances for verbs 'agree' that are explicitly uttered and utterances that show implicit acceptance as informatives speech acts.

1. tajuk ni pun sesuailah [K1 (leader group one)]

2. setuju, setuju [K8 (leader group eight)]

Based on the two examples mentioned above, it is clear that the group leader played a role in making assentives speech acts during the small group discussion. This assentives speech acts was found to be used by the group leader regardless of whether at the beginning, middle or end of the discussion. The statement of the leader of the first group (K1) is that "tajuk ni pun sesuailah" clearly shows the act of acceptance. As a leader, (K1) needs to respond to what his group members say. This is because the response will speed up the discussion time and will not waste time. (K1) is seen to be making acceptance of the proposed topic as a result of their group discussion. The statement of assentives of (K1) was uttered at the end of the discussion. Although the utterance of (K1) is not marked by performative verbs for the language of acceptance, but the utterance can clearly be connoted as a treatment of acceptance. The word "sesuai" according to the Kamus Dewan Edisi Keempat (2014) is a true match. Thus, this shows that (K1) thinks that the proposed title is appropriate and acceptable. A leader needs to state his position firmly whether or not to accept whatever is discussed in a group so that time can save time and firm decisions can be made. Fisher (1980) states that a group leader should be firm in making decisions about his organization including accepting and rejecting suggestions given by his members. Therefore, the act of accepting behavior expressed by (K1) is seen as a positive thing to ensure that the discussion runs smoothly and achieves its goals.

The statement of the leader of the eighth group is "setuju, setuju" clearly shows the assentives speech acts. The word 'setuju' is repeated twice which shows the emphasis on acceptance. 
The word "setuju" is an explicit performative verb that is "agree" as outlined by Bach and Harnish (1979) in his speech acts theory. Thus, this clearly shows that (K8) has the intention of assentives speech acts. This act of acceptance is seen to be able to speed up the discussion time when there is a response from group members who receive the suggestions made. Therefore, as the group leader, the role played by making assentives speech acts is very useful as a sign of acceptance of what is being discussed. The group leader is seen using this assentives speech acts regardless of whether it is at the beginning, middle or end of the discussion.

\section{v) Suggestives}

Refer to the Kamus Dewan Edisi Keempat (2010), the meaning of suggestives is purpose of a proposal is to submit an opinion to be agreed or considered by the listener. Bach and Harnish (1979) states that verbs that can express the suggestives are conjecture, guess, hypothesize, speculate and suggest. Based on the communication data of these successful small group leaders, only verbs (cadang) 'suggest' are used by the group. Below are examples of suggestives utterances using the verb 'suggest'.

1. aku cadangkan kita ambik pengaruh bahasa pijin, sebab dalam konteks ni kita boleh cerita dari pelbagai aspeklah. [K1 (leader group one)]

\section{2. kalau macam tu aku cadangkan cerita yang dialek-dialek la. [K8 (leader group eight)]}

The two examples of the group leader's statement above were uttered in the middle of the discussion because at that time there were many suggestions to be made. As an example of (K1) statement that is "aku cadangkan kita ambik pengaruh bahasa Pijin, sebab dalam konteks ni kita boleh cerita dari pelbagai aspeklah". This verse clearly shows the suggestions made by a leader to his group members. This (K1) utterance is marked by the performative verb "cadangkan" which is "suggest". Therefore, this utterance clearly shows the intention of the proposed speech acts. Such suggestions are very much needed in group discussions because giving suggestions will further accelerate efforts to achieve the objectives of the discussion and save discussion time. Therefore, (K1) is seen to play a role as a leader well because it gives useful suggestions and does not waste time. This suggestion is very useful because the members of his group will listen and consider whether to accept it or not.

Next is the statement by the leader of the eighth group, (K8) "kalau macam tu aku cadangkan cerita yang dialek-dialek la". This utterance clearly shows the suggestives speech acts because there is the performative verb "cadangkan". Bach and Harnish (1979) stated that the verb "suggest" which carries the meaning of proposal is the practice of suggested language. (K8) is seen making suggestions to his group members regarding the selection of study materials. Such suggestions are very useful in small group communication with allocated time and targeted objectives. The suggestives speech acts will be discussed with the group members whether it is relevant or not to be accepted. If relevant, the proposal can be accepted and used in their study. The suggestives speech acts is spoken by the group leader at the beginning of the discussion until the middle part of the discussion. The suggestions put forward will be discussed in more depth whether they are acceptable or not. Based on all the utterances of 
the suggestives speech acts uttered by the group leaders, it is clear that the group leader uses the suggestives speech acts during the initial and middle phases of the discussion only.

\section{vi) Requestives}

According to Bach and Harnish (1979), requestives speech acts is the desire expressed by the speaker who wants the listener to do something. This means that the intention of the speaker's speech is used as an excuse for the listener to implement what the speaker is saying. Bach and Harnish (1979) states that verbs that can express the requestives are ask, beg, beseech, implore, insist, invite, petition, plead, pray, request, solicit, summon, supplicate, tell and urge. This study found that small group leaders only use the verbs 'ask' and 'request' in the utterances of requestives. However, there are also those who express the requestives speech acts implicitly by using words such as "nak" or "mahu". The example given below only refers to utterances that contain the verb 'ask' and the word 'nak'.

\section{1. nak minta cuba korang fikir-fikirkan apa tajuk yang sesuai nak buat ni, mesti} dalam bidang bahasa jer. [K1 (leader group one)]

\section{2. tak sekarang aku nak kita bincangkan bahagian objektif jer dulu. [K7 (leader group seven)]}

Statement in 1 above shows an instruction from the group leader, (K1) who asked his group members "nak minta cuba korang fikir-fikirkan apa tajuk yang sesuai nak buat ni, mesti dalam bidang bahasa jer". This statement clearly shows a leader making a request to his group members to think of a topic to be proposed to meet the needs of the discussion. This (K1) utterance is marked by the performative verb "minta" which is "ask" as outlined by Bach and Harnish (1979). The presence of this request verb makes this (K1) directive statement explicit. The verb "minta" is used as an indicator to show the intention of the requestives speech acts which clearly carries the meaning of the speaker's desire to the listener to do what he asked without any hesitation. This request is very clear and useful in order to ensure that the objectives of the discussion are achieved. As a leader, suggestives speech acts is very appropriate to say to his group members to do something. A leader also needs to give clear instructions so that his members can understand and do as requested.

Apart from that, the leader of the seventh group, (K7) is also seen to play a role in giving instructions to ask. (K7) made a request to ask his group members to discuss the objectives first. This request was made because the members of his group at that time did not have a structured discussion and discussed many things at one time. Therefore, the discussion is not focused. So (K7) as the leader plays a role by stating a request for his group members to discuss the objectives first. This (K7) utterance is marked with the word "nak" which is an abbreviated oral language from the word 'hendak' (want). The word "nak" mean the leader wants something to happen and at the same time its members can do it and admit it is the best for the speaker. The use of the language of request language through this word "nak" shows the firmness shown by a leader to be heard by his group members. (K7) is seen asking his group members to discuss the objectives of the study first, then other matters. The instructions given by (K7) are seen as very useful and serve as instructions to be followed for the good of their group. The (K7) utterance is uttered at the beginning of the discussion which is an instruction for the members of the group to think of an appropriate topic, while the (K1) 
utterance is uttered in the middle of the discussion asking for the objective to be discussed first. Both of these requests should be uttered by a leader as these acts will be heard by group members and they will comply with the request.

\section{vii) Questions}

The questions speech acts means a special case against the request. The special refers to the information given by the listener to the speaker at the request of the speaker. Bach and Harnish (1979) states that verbs that can express the questions are ask, inquire, interrogate, query, question and quiz. This study found that small group leaders only use the verbs 'ask' and 'question' in the utterances of questions speech acts that are explicitly pronounced. However, there are also utterances of questions speech acts that use question words such as what, why, how and so on. The example given below only refers to utterances that contain verbs 'ask' and questions words 'apakah' (what).

\section{1. okay apakah objektif yang kita mahu gunakan dalam kajian? [K7 (leader group seven)]}

\section{2. aku nak tanya apa dia definisi budaya? [K9 (leader group nine)]}

In sentence (1), the seventh group leader, (K7) used the questions speech acts which is done by using open questions. Open questions will use question words such as what, who, why, how, how much and so on (Omar, 1987). The use of question words in a sentence is known as a question sentence with a question element. (K7) statement is "okay apakah objektif yang kita mahu gunakan dalam kajian?" clearly shows the question word "apakah" is "what" used for questioning. Although this utterance of (K7) is not marked by the explicit performative verb of the language of the question, it clearly shows the intention of the act of asking. This (K7) statement clearly shows that the group leader use the question word to make a statement of the intention of asking questions in group discussion. According to Karim, Onn, Musa, Mahmood and Aman (2015), the use of question words such as when, what, where, who in a sentence is known as a question sentence with a question element. Each question asked will be answered by another group member. If other group members also do not know about it, then the answers shared will be known by all group members. Therefore, this question is very important because group members can find out about new things.

In sentence (2) above, the statement by (K9) is "aku nak tanya apa dia definisi budaya?" This utterance is marked by the explicit performative verb "tanya" which is "ask" as outlined by Bach and Harnish (1979). This example clearly shows the intention of the questions speech acts because it is marked with the question verb. The use of this question verb is seen to emphasize the speaker's desire to get an information response from his group members. According to Kempson (1991), in oral communication, question sentences can serve as instructions for obtaining information or responses. Thus, the utterances of (K7) and (K9) clearly indicate an instruction given to obtain feedback from the members of their respective groups. The presence of the question word in the group leader's utterance shows his firmness towards what is intended to make the group members more easily respond to the instructions uttered. The determination of the group leader shows the intention and desire to get information by using the question verb also causes the group members to better understand what the leader directs. 


\section{The Role of Group Leaders and speech acts}

An analysis of the speech acts on four group leaders has showed that the group leaders played an important role as a leader. The leaders of these groups also managed to use certain speech acts on a regular basis. There are only seven subcategories of speech acts used, namely assertives, descriptives, informatives, assentives, suggestives, requestives and questions. Other types of speech acts subcategories are not used by the leaders of these small groups. Below are details of the frequency of speech acts used for the four successful small groups.

Table 2: Speech acts used by small group leaders

\begin{tabular}{|c|c|c|c|c|c|}
\hline $\begin{array}{c}\text { Subcategorise } \\
\text { of speech acts }\end{array}$ & $\begin{array}{c}\text { Leader group } \\
\text { one }\end{array}$ & $\begin{array}{c}\text { Leader group } \\
\text { seven }\end{array}$ & $\begin{array}{c}\text { Leader group } \\
\text { eight }\end{array}$ & $\begin{array}{c}\text { Leader group } \\
\text { nine }\end{array}$ & Total \\
\hline Assertives & 4 & 2 & 4 & 3 & 13 \\
\hline Descriptives & 3 & 2 & 2 & 2 & 9 \\
\hline Informatives & 1 & 1 & 1 & 3 & 6 \\
\hline Assentives & 2 & 1 & 1 & 3 & 7 \\
\hline Suggestives & 4 & 3 & 3 & 5 & 15 \\
\hline Requestives & 1 & 1 & 2 & 2 & 6 \\
\hline Questions & 4 & 9 & 7 & 4 & 24 \\
\hline
\end{tabular}

Based on table 2 above, it can be clearly seen the results of speech acts by successful small group leaders, namely leader group one, seven, eight and nine. The subcategory of the questions is seen have the highest is 24 utterances followed by the suggestives is 15 utterances and the assertives is 13 utterances. All these speech acts used were well utilized by the group leader to ensure that the utterances of the spoken language can be understood by its members. Based on the analysis of the utterances of the leaders of these small groups, clear speech acts with the explicit use of performative verbs is seen to contribute to the success of a small group discussion compared to the use of indirect speech acts that is implicit. According to Bach and Harnish (1979), communication becomes effective when the speaker's utterance intentions can be easily detected by the listener and the listener can act as intended by the speaker through utterance. Therefore, group leaders need to be proficient in communicating using speech acts utterances that contain explicit performative verbs in order to be well understood. The implicit use of speech acts that does not use certain performative verbs requires accurate interpretation so as not to be misinterpreted in conveying the meaning of the utterance. Zainal, Mydin and Musanif (2018) stated that speech implicitly requires effort from the listener to interpret the meaning of the speaker and such efforts will fail if they do not know the correct method. Therefore, small group leaders are advised to recite clear and easy-to-understand speech acts which are speech acts that use explicit performative verbs.

Based on the analysis, the speech acts of the leaders are uttered explicitly and implicitly. For explicit utterances, performative verbs are used as ilocution markers to identify the speech acts used. Explicit performative verbs clearly indicate the intention of the speaker's act and act as an eloquent force that names the act in a speech acts. While to identify the intention of the speaker's act in implicit speech, context-based description needs to be done. Implicit utterances do not contain verbs that indicate the intention of the speaker's act clearly in a sentence. On the other hand, the intention of the speaker's treatment can be connoted and its purpose understood based on the context and situation of the utterance. Small group 
leaders need to know the types of speech acts that are appropriate to use and their functions. This is because effective speech acts can be produced when the group leader masters the form of the speech acts (Hughes, 1984). These four successful small group leaders have successfully proven that language plays an important role in determining the success of a group discussion. Because the group leader plays a role by using effective speech acts, discussion time can be saved as well as achieve the outlined discussion goals. The examples of utterances analyzed in this study can be used as a guide to see the role of a group leader through the use of effective speech acts.

Analysis of previous studies found that a small group discussion will successfully achieve the goal of the discussion within a set period of time due to various factors other than the use of language. Among the factors that make a small group successful are based on the social skills of its members, mastery of discussion topics, resources and ideal group size (Hargie, 2012). However, this study successfully proves that the role of a leader in terms of the use of his language influences and determines the success of a small group. The effective use of language by a group leader can make a small group successful by adhering to the set time and achieving the objectives outlined. As emphasized by Hanna and Richards (2019), the use of speech acts should be given attention in communication because the use of speech acts very important in determining the success of such communication. Therefore, in order to produce a quality small group discussion, the leader needs to play a role by mastering the linguistic aspect of understanding the function of speech acts and articulating it effectively. All examples of group leader utterances analyzed in this study can be used as a guide and reference to small group leaders who are given the responsibility to conduct a discussion.

\section{Conclusion}

Based on the major findings of this study, the leaders of small groups who successfully play the role of a leader by using effective speech acts and they also utter speech acts explicitly and implicitly very clearly. Among the types of speech acts used by small group leaders are assertives, informatives, suggestives, descriptives, assentives, requestives and questions. Therefore, this study suggests that someone who will be the leader of a small group in the future needs to understand the function of speech acts in order sto be able to utter it effectively. The group leader can see the types of speech acts that are appropriate to use based on the frequency shown in this study and how the speech acts are used through the examples of utterances given in the analysis section of this study. The suggestions given are very beneficial to group leaders who are responsible for conducting a group discussion. In order to produce excellent group leaders, they need to be good in communicating, understanding the function of speech acts and using the speech acts clearly so that the group they lead runs smoothly.

\section{References}

Adam, Z., \& Kassim, F. (2011). Kemahiran kerja berpasukan: etika dalam pekerjaan dari perspektif Islam. http://malrep.uum.edu.my/rep/Record/my.iium.irep.7989 [10 Oktober 2020].

Austin, J. L. (1962). How to do Things with Words. Oxford: Clavendon Press.

Bach, K., \& Harnish, R. M. (1979). Linguistic Communication and Speech Acts. London: The MIT Press. 
Beebe, S. A., \& Masterson, J. T. (1994). Communication in Small Group: Principles and Practices. New York: Harpercollins.

Blakemore, D. (1992). Understanding Utterance. Oxford: Blackwell Publishers.

Cargan, J. F., \& Wright, D. W. (1980). Communication in Small Group Discussion. New York: West.

Desmond J. L., Steven G. R., Peter B. W., \& Jenifer L. B. (2009). Perceived meeting effectiveness: the role of design characteristics. J Bus Psychol, 24, 65-76.

Devito, J. A. (1997). Human Communication: The Basic Course. New York: Logman.

Ellis, D. G., \& Fisher, B. A. (1994). Small Group Decision Making. New York: McGraw-Hill.

Firestien, R. L. (1990). Effect of creative problem solving training on communication behavior in small group. Small Group Research, 21, 507-521.

Fisher, B. A. (1980). Small Group Decision Making: Communication and the Group Process. New York: McGraw-Hill.

Hanna, N., \& Richards, D. (2019). Speech act theory as an evaluation tool for human-agent communication. Algorithms, 12(79), 2-17.

Haynes, M. E. (1988). Effective Meeting Skills: A Practical Guide For More Productive Meetings. United States of America: Crisp Publications.

Hirvonen, P. (2016). Positioning theory and small-group interaction: social and task positioning in the context of joint decision-making. SAGE, 20(6), 1-15.

Hughes, R. L., Ginnet, R. C., \& Curphy, G. J. (1999). Leadership: Enhancing the Lessons of Experience. Boston: Irwin McGraw-Hill.

Hyland, B., \& Yost, M. (1994). Reflections for Managers. New york: McGraw-Hill

Ibrahim, R., Hasan M. R., \& Hamid, B. A. (2018). Takrif kepimpinan, ciri-ciri pemimpin dan motivasi untuk memimpin menurut sudut pandang pemimpin wanita akar umbi. Jurnal Pengajian Umum Asia Tenggara, 19, 28-42.

Ibrahim, S. H., Nordin, S. A., Delin, S. H. M., Baharudin, S. T., Fakurazi, Z., \& Saad, S. (2017). Peranan dan pengaruh pemimpin pendapat dalam menggalakkan masyarakat kampung terlibat dalam aktiviti koperasi: kajian kes di Kampung Hulu Chuchoh, Sepang. Journal of social Science and Humanities, 2, 034-048.

Juhari, A., \& Hamzah, Z. A. Z. (2015). Penggunaan lakuan pertuturan dalam mesyuarat. Jurnal Persatuan Linguistik Malaysia, 19(1), 48-57.

Karim, N. S., Onn, F. M., Musa, H. H., Mahmood, A. H., \& Aman, M. S. (2015). Tatabahasa Dewan. Kuala Lumpur: Dewan Bahasa dan Pustaka.

Katip, K., Bakar, B. A., \& Malia, F. F. (2005). Tinjauan perlaksanaan pembelajaran berkumpulan di kalangan pelajar institusi pengajian tinggi swasta (IPTS) di Johor Bahru. Prosiding Seminar pendidikan, hlm. 1-7.

Kechot, A. S. (2015). Bentuk komunikasi dalam menangani peranan kepimpinan badan bukan kerajaan (NGO) perfileman. Malaysian Journal of Communication, 31(2), 423-439.

Mahbob, M. H., Ali, N. A. S. M., Sulaiman W. I. W., \& Mahmud, W. A. W. (2019). Komunikasi strategik dan peranannya untuk mewujudkan komunikasi berkesan dalam organisasi. Malaysian Journal of Communication, 35(2), 49-67.

Mahmood, A. (2000). Konsep pertanyaan berdasarkan teori lakuan pertuturan Melayu. Jurnal Dewan Bahasa, 44(12), 1318-1329.

Napier, R. W., \& Gershenfeld, M. K. (1993). Groups: Theory and Experience. Boston: Houghton Mifflin.

Omar, A. H. (1987). Bahasa Malaysia Saintifik. Kuala Lumpur: Dewan Bahasa dan Pustaka. 
Omar, A. H. (1997). Penggunaan Bahasa dalam Surat Rasmi dalam Komunikasi. Kuala Lumpur: Dewan Bahasa dan Pustaka.

Omar, A. H. (2007). Kesantunan Bahasa dalam Pengurusan Pentadbiran dan Media. Kuala Lumpur: Dewan Bahasa dan Pustaka.

Osman, W. R. M., Wahab, H. A., \& Kamil, S. T. (2010). Penggunaan Bahasa Dalam Sesi Kaunseling Dari Sudut Lakuan Bahasa. Jurnal Bahasa. 10 (1), 54-73.

Ruth, M. K. (1991). Teori semantik. Kuala Lumpur: Dewan Bahasa dan Pustaka.

Saedan, S. R., Jamil, N. I. M, \& Ramachanderam, S. (2017). Kajian kepuasan bekerja secara berkumpulan pelajar semester 4 (JKE \& JKM) Sesi Jun 2016. https://www.semanticscholar.org/author/I-Ramachanderam/147358104 [2 Ogos 2020]

Searle, J. L. (1962). Meaning and Speech Acts. London: Duke University Press.

Searle, J. (1969). Speech Act: An Essay in the Philosophy of Language. London: Cambridge University Press.

Tamam, E. (1999). Menjayakan Komunikasi Kumpulan Kecil. Serdang: Penerbit Universiti Putra Malaysia.

Zainal, M. Z., Mydin, A., \& Musanif, A. M. (2018). Makna penutur bagi ujaran tak langsung dalam skrip drama bahasa Melayu. Malaysian Journal of Communication, 34(2), 243262. 